Portland State University

PDXScholar

\title{
Where Have All the Native Fish Gone? The Fate of Fish that Lewis and Clark Encountered on the Lower Columbia River
}

Virginia L. Butler

Portland State University, virginia@pdx.edu

Follow this and additional works at: https://pdxscholar.library.pdx.edu/anth_fac

Part of the Archaeological Anthropology Commons, and the Biological and Physical Anthropology Commons

Let us know how access to this document benefits you.

Citation Details

Butler, V. L. (2004). Where Have All the Native Fish Gone? The Fate of Fish that Lewis and Clark Encountered on the Lower Columbia River. Oregon Historical Quarterly, 105(3), 438-463.

This Article is brought to you for free and open access. It has been accepted for inclusion in Anthropology Faculty Publications and Presentations by an authorized administrator of PDXScholar. Please contact us if we can make this document more accessible: pdxscholar@pdx.edu. 


\section{Virginia L. Butler}

\section{Where Have All the Native Fish Gone?}

\section{The Fate of Fish That Lewis and Clark Encountered on the Lower Columbia River}

$\mathrm{F}$

ISH HAVE BEEN PART OF THE FABRIC of Northwest peoples' lives for thousands of years. History, archaeology, and oral traditions of living peoples make this long-term connection clear. A nineteenth-century engraving by John Mix Stanley shows a group of Indians camped on a large sandbar near The Dalles, Oregon Territory, in 1853 . One individual is in a canoe, others are moving gear, and strips of what appear to be fish are drying over a simple frame. About a hundred years after the engraving was made, University of Oregon archaeologists digging just a few hundred meters to the left of the tents seen in the image recovered thousands of fish bones, mainly from salmon, that date to 7,000 BCE. ${ }^{1}$ The juxtaposition of the ancient archaeological fishing site and the historic image illustrates the connections among people, place, and fish across a vastness of time that is almost unimaginable. Yet, hundreds of archaeological sites dating to the past ten thousand years found throughout the Pacific Northwest contain fish bones from salmon, sturgeon, and countless other varieties of fish, establishing their importance to Native peoples' lifeways for this lengthy period of time.

The two-hundred-year anniversary of the expedition of Lewis and Clark and the Corps of Discovery provides an opportunity to reflect on the history and current status of our region's fish populations. The journals the explorers kept on the lower Columbia River - from what they called the Cascades of the Columbia, near present-day Bonneville Dam, to the 


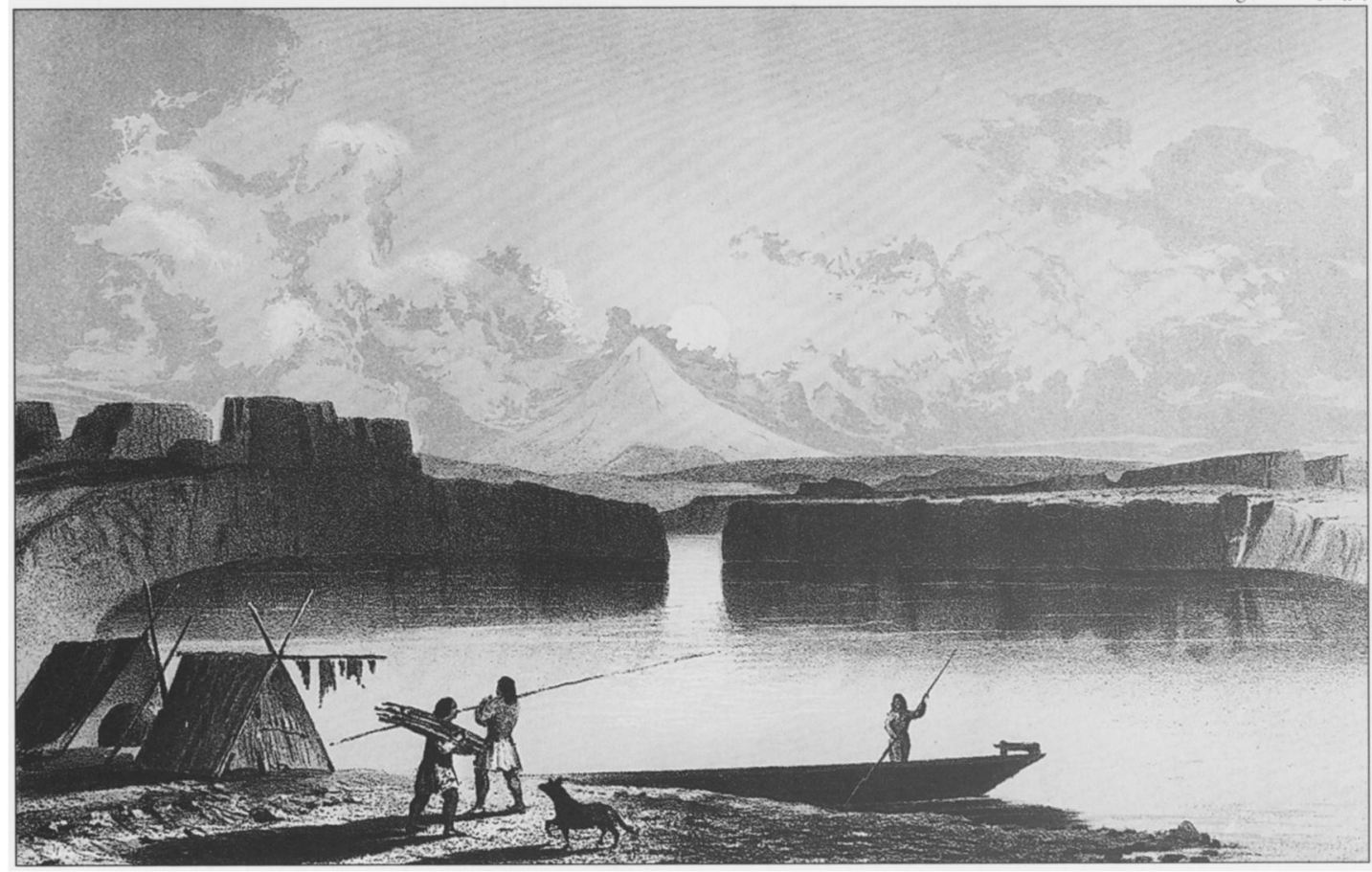

The Indian camp in this 1853 engraving, Columbia River area Indian camp at The Dalles, Oregon, by John Mix Stanley, was located on Fivemile Bar, just upstream from the entrance to Fivemile Rapids. In the 1950s, thousands of salmon remains were recovered from an archaeological site (35ws8) established in the area to the left of where the tents are here.

mouth - provide the first written descriptions of several fish, indicate how much the group relied on fish for sustenance, and show the importance of fish to Native Americans. Archaeological records of fish remains from villages that date to the time of the expedition provide additional information on the kinds and abundance of fish living in the river and adjacent wetlands on the floodplain. When these roughly two-hundred-year-old fish records are compared to modern records from the lower Columbia, the differences are profound, and they highlight the magnitude of change that has occurred in a relatively short period.

\section{Lower Columbia River Fishes, ca. 1800}

The Lewis and Clark Expedition left the Cascades of the Columbia on November 2, 1805, and canoed downstream to the mouth of the river, where they established a permanent camp, Fort Clatsop, on December 8. On March 23, 1806, the group left the mouth and canoed back upstream 
Adapted from The Journals of the Lewis and Clark Expedition, vol. 6, ed. Gary E. Moulton, by permission of the University of Nebraska Press. Copyright (c) 1990 by the University of Nebraska Press.

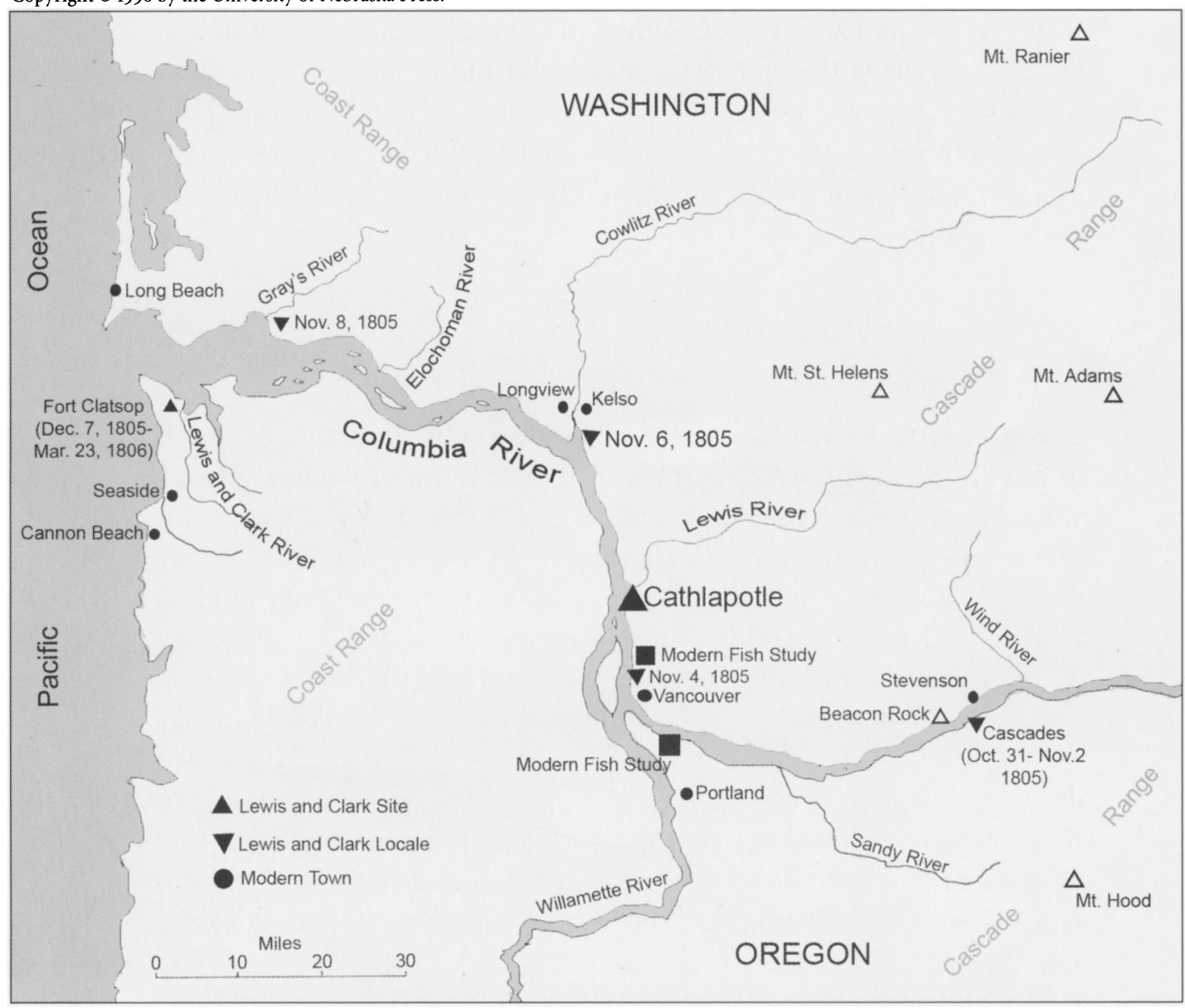

Map 1. The explorers' route along the Columbia River, November 2, 1805-March 22, 1896, and modern archaeological study sites

to the Cascades, arriving there on April 13 (see map 1). The explorers' journals record observations and experiences each day for 163 days during this period, registering foods that they hunted or fished, their interactions with Native Americans (including trading for fish to eat), and their observations of plants and animals in the immediate area.

The explorers were visiting the lower Columbia when fish were relatively scarce. The Columbia River system is best known for its huge runs of anadromous salmon and trout, which, in the nineteenth century, may have numbered 16 million individual fish. ${ }^{2}$ Most of these fish entered the river from the saltwater of the Pacific and migrated through the lower river between April and October - not during the winter and early spring, 
when Lewis and Clark visited. Although the explorers were traveling in the region during the off-season for at least the primary salmon runs, their journal entries show that the Corps commonly ate fresh fish. They also made great use of dried salmon, which the group had purchased from Indians at the Great Falls of the Columbia, in the vicinity of The Dalles, in October 1805.

\section{Which Fish Species Did Lewis and Clark Observe on the Lower Columbia?}

LEWIS AND CLARK WROTE ABOUT encounters with seven different kinds of fish during their lower Columbia visit: three forms of salmon or trout, sturgeon, flounder, "skait," and "anchovie." The detail they provided for each type of fish varies considerably, and even fish they described in some detail, such as the salmonids (salmon and trout), are difficult to link to known species because of the degree of phenotypic variation within and between species. In addition, salmonids undergo significant physical changes in color and shape as they enter fresh water and become sexually mature. What Lewis and Clark viewed as separate species based on striking differences in color, for example, could represent different populations of the same species, different sexes, or differing phases of sexual maturation (see, for example, the coho and chum salmon on the back cover of this issue). The Corps did not collect fish for later examination by ichthyologists. Such problems notwithstanding, previous Lewis and Clark scholars — including Elliott Coues, Raymond D. Burroughs, Paul R. Cutright, and Gary E. Moulton - have attempted to use Lewis and Clark's descriptions to assign fish to particular species. ${ }^{3}$ Some of these assignments may not be correct, while others are speculative (see table 1 ).

On November 11, for example, Clark wrote that they purchased thirteen "red charr" from Indians traveling in a canoe filled with fish. ${ }^{4}$ This transaction occurred while Clark and some of the group were camped on the north side of the estuary, close to the mouth of the Columbia. Cutright, Burroughs, and Moulton have asserted that "red charr" is sockeye salmon (Oncorhynchus nerka), presumably because sockeye salmon takes on a red color as it becomes sexually mature during spawning. ${ }^{5}$ I question this species assignment on two counts. First, sockeye salmon populations require lakes connected to streams as part of their spawning habitat. Historically, the nearest lakes that supported sockeye salmon were Quinault and Ozette, 150 kilometers or more north of the Columbia River estuary on 
Table 1. Fish recorded by Lewis and Clark on the lower Columbia River and adjacent coastal area (November 2, 1805-April 16, 1806)

\begin{tabular}{|c|c|c|}
\hline $\begin{array}{l}\text { Lewis and } \\
\text { Clark's name }\end{array}$ & $\begin{array}{l}\text { Scientific name assigned by } \\
\text { other researchers }\end{array}$ & $\begin{array}{l}\text { Scientific name assigned } \\
\text { in this study }\end{array}$ \\
\hline red charr & $\begin{array}{l}\text { Oncorhynchus nerka } \\
\text { (Cutright, Burroughs, Moulton) }\end{array}$ & O. kisutch? O. keta? \\
\hline salmon trout & $\begin{array}{l}\text { O. mykiss } \\
\text { (Cutright, Burroughs, Moulton) }\end{array}$ & O. mykiss? O. kisutch? O. keta? \\
\hline white salmon trout & $\begin{array}{l}\text { O. kisutch } \\
\text { (Buttoughs, Cutright) }\end{array}$ & O. mykiss? \\
\hline \multirow[t]{2}{*}{ sturgeon } & $\begin{array}{l}\text { Acipenser transmontanus } \\
\text { (Coues) }\end{array}$ & Acipenser sp. \\
\hline & $\begin{array}{l}\text { A. mediristoris } \\
\text { (Moulton) }\end{array}$ & \\
\hline anchovie, anchovey & Thaleichthys pacificus & Thaleichthys pacificus \\
\hline flownder & $\begin{array}{l}\text { Platichthys stellatus } \\
\text { (Moulton, Coues) }\end{array}$ & Pleuronectidae \\
\hline skeet, skaite, skait & $\begin{array}{l}\text { Raja binoculata, R. ornata } \\
\text { (Moulton, Coues) }\end{array}$ & Raja or Bathyraja sp. \\
\hline
\end{tabular}

the Washington coast. In the Columbia River system, the nearest sockeyespawning habitat was well above Celilo Falls, hundreds of kilometers from the river's mouth. ${ }^{6}$ Given the scarcity of suitable spawning habitat nearby where sexually mature sockeye salmon could be taken, it is improbable that Clark's "red charr" was sockeye. Second, the sockeye salmon migration season extends from late spring until late summer, several months from the time Clark purchased the fish.

Based on spawning habitat preference and seasonal migration period, it is much more likely that "red charr" is coho (O. kisutch) or chum salmon (O. keta). Coho salmon spawn in coastal streams along the Washington and Oregon coast near the Columbia River mouth and in tributary streams in the estuary. Most coastal coho populations begin to enter freshwater between mid-September and mid-November and spawn within a week of entering the spawning ground. Chum salmon also spawn in streams of the lower Columbia, with their spawning season occurring from Oc- 
tober through December.7 Describing "red charr," Lewis wrote that "some of them are almost entirely red on the belley and sides; others are much more white than the salmon [ chinook salmon (O.tshawytscha)] and none of them are variagated with the dark spots which make the body of the other." ${ }^{\prime}$ As coho, particularly males, approach sexual maturity, their silvery appearance changes to deep red, much like the fish Lewis described. ${ }^{9}$ On the other hand, Lewis emphasized the lack of dark spots on "red charr." While smaller and less pronounced than those on chinook salmon, coho salmon do have black spots on their back. Chum salmon lack black spots, consistent with Lewis's description, but they do not turn a uniform red color during spawning. Overall, identifying "red charr" as coho or chum salmon can be only tenuous.

Burroughs, Cutright, and Moulton have suggested that a second salmonid the explorers called "salmon trout" is steelhead trout $(O$. mykiss). Clark purchased "salmon trout" from Indians on November 6 in the vicinity of the Cowlitz River, roughly ninety kilometers from the mouth of the Columbia; and on November 12 and 13, Clark and some of his men captured about sixteen "salmon trout" in a creek on the north side of the Columbia estuary. ${ }^{10}$ On March 13, Clark provided a detailed description:

The Salmon Trout are Seldom more than two feet in length, they are narrow in purportion to their length, at least much more So than the Salmon \& red charr. ... at the Great Falls [Montana] are met with this fish of a Silvery white colour on the belly and Sides, and a blueish light brown on the back and head. in this neighbourhood we have met with another Species which does not differ from the other in any particular except in point of Colour. this last is of a dark colour on the back, and its Sides and belley are yellow with transverse Stripes of dark brown. Sometimes a little red is intermixed with these Colours on the belly and Sides towards the head."

Clark explained as well that "salmon trout" could be seen with "red charr" in the creeks draining into the estuary in November. ${ }^{12}$ It is possible that "salmon trout" is steelhead trout, as some historians have suggested. Some steelhead trout populations in the Columbia River system enter the river between November and April and spawn in the tributaries below the Cascades, including several creeks and rivers near the mouth. ${ }^{13}$ But perhaps Clark's "salmon trout" refers to female coho salmon - which lack the striking red color of the male - or to male or female coho salmon in earlier phases of sexual maturation, which would lack the brighter spawning colors. Yet another possibility is that he was seeing chum salmon $(O$. keta). The species assignment is ambiguous. 
A third salmonid that Lewis and Clark recorded, "white salmon trout," was assigned to the species coho salmon by Burroughs and Cutright. ${ }^{14} \mathrm{On}$ March 16, Lewis wrote that the fish were entering creeks near Fort Clatsop; and on April 10, just before arriving at the Cascades on their return trip, the Corps purchased four "white salmon trout" from Native Americans. ${ }^{15}$ Lewis described this fish in some detail:

it was 2 feet 8 Inches long, and weighed 10 lbs. the eye is moderately large, the puple black and iris of a silvery white with a small addmixture of yellow, and is a little terbid near it's border with a yellowish brown.... [the fins] are small in proportion to the fish. the fins are boney but not pointed except the tail and back fins which are a little so, the prime back fin and ventral ones, contain each ten rays; those of the gills thirteen, that of the tail twelve, and the small fin placed near the tail above has no bony rays, but is a tough flexable substance covered with smooth skin. it is thicker in proportion to it's width than the salmon. the tongu is thick and firm beset on each border with small subulate teeth in a single series. ${ }^{16}$

Based on the spawning migration period, however, it is unlikely that "white salmon trout" refers to coho salmon. As noted above, Columbia River coho salmon migrate into freshwater in the fall, not late winter and early spring. A more likely candidate for "white salmon trout" is steelhead. We know that some steelhead populations migrate into lower Columbia tributaries in winter and spring. At least based on spawning location and seasonality, "white salmon trout" more closely matches winter-run steelhead than coho salmon.

In his November 18 entry, Clark recorded seeing flounder on the beach north of Cape Disappointment: "we found a Curious flat fish Shaped like a turtle, with fins on each side, and a tale notched like a fish, the Internals on one Sid and tale \& fins flat wise This fish Flownder has a white $<$ belly $>$ on one Side \& lies flat to the Ground-." Moulton, following Coues, has claimed that this specimen was probably a starry flounder (Platichthys stellatus). Multiple species of flatfish (family Pleuronectidae) matching this description occupy North Pacific waters near the shore, however; and with such limited information, species assignment is speculative. ${ }^{17}$

While walking on the Oregon coast north of the present-day community of Seaside on January 7, Clark "found a Skeet fish [X: Skaite] which had been lef by the tide." ${ }^{18} \mathrm{He}$ included only a rough sketch. Moulton has suggested that the "Skeet" refers to Raja binoculata (big skate), while Coues has asserted it was $R$. binoculata or $R$. inornata (California skate). ${ }^{19}$ At least four other species of skate (genus Raja and Bathyraja) are known for this region and could have washed up on the beach. ${ }^{20}$ Each species has distinc- 
tive coloration, body shape, and surface spine patterns. Given the limited description, however, assigning Clark's fish to a species is tenuous.

The explorers mention sturgeon in multiple entries. On November 19, while walking on Long Beach north of Cape Disappointment, Clark observed: "I saw a Sturgeon which had been thrown on Shore and left by the tide 10 feet in length." ${ }^{21}$ Coues has asserted that this was white sturgeon (Acipenser transmontanus), presumably based on its large size. ${ }^{22}$ White sturgeon is known to reach lengths of six meters (about twenty feet), while another species known for the northeastern Pacific and river estuaries, green sturgeon (A. medirostris), is considerably smaller, attaining lengths of just over two meters (around seven feet). ${ }^{23}$ Moulton has suggested that Clark probably exaggerated the size and has asserted that Clark saw a green sturgeon. ${ }^{24}$

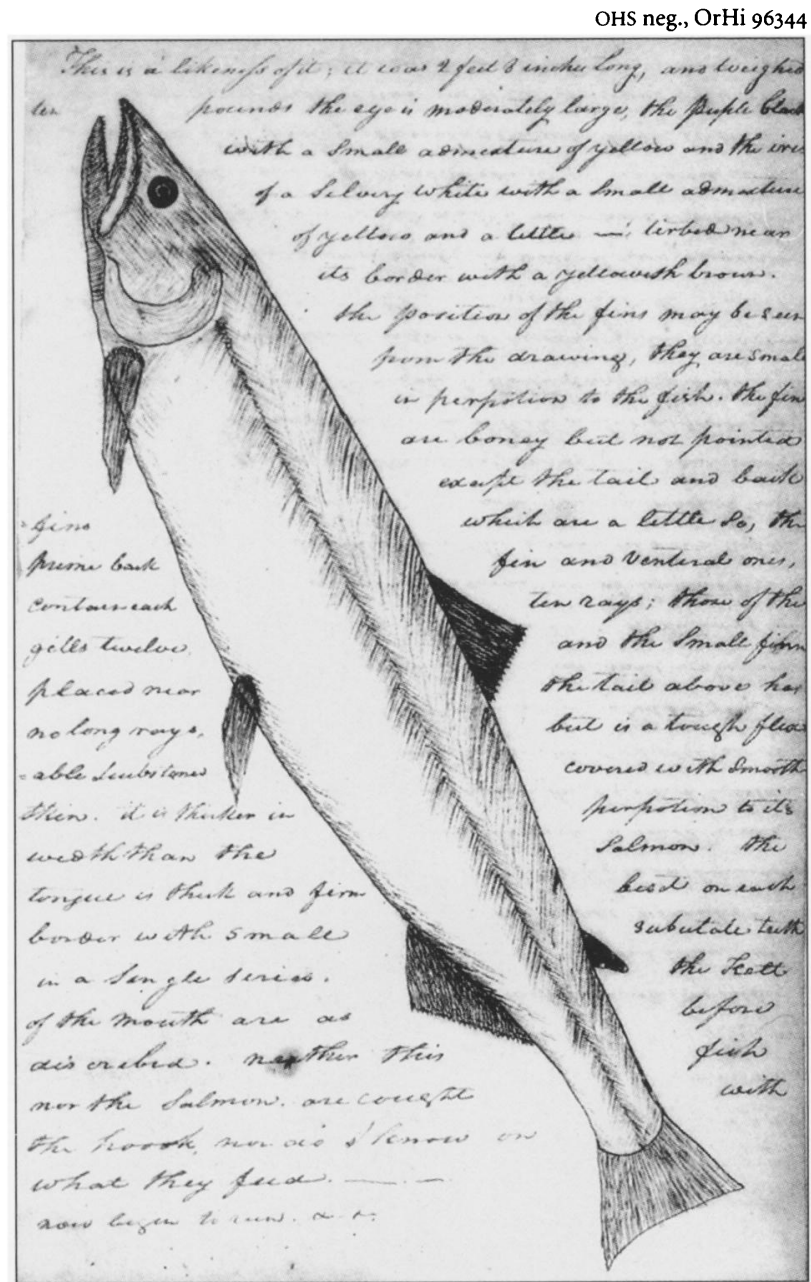

William Clark's drawing of a fish he called a white salmon trout was reproduced in Reuben Gold Thwaites's edition of the explorers' journals, published in 1904-1905. Moulton's reasoning is flawed here, given that a smaller sturgeon could represent either species. Overall, given the limited information and ambiguity about size estimates, species determination is speculative.

The fish to which Lewis and Clark devoted the most attention during their lower Columbia stay is one they called "anchovie." The explorers provided detailed anatomical descriptions and drawings and noted seasonal migration patterns for this fish. Unique characteristics of the species allow for unambiguous species assignment to Thaleichthys pacificus, commonly known as eulachon, a member of the smelt (Osmeridae) 


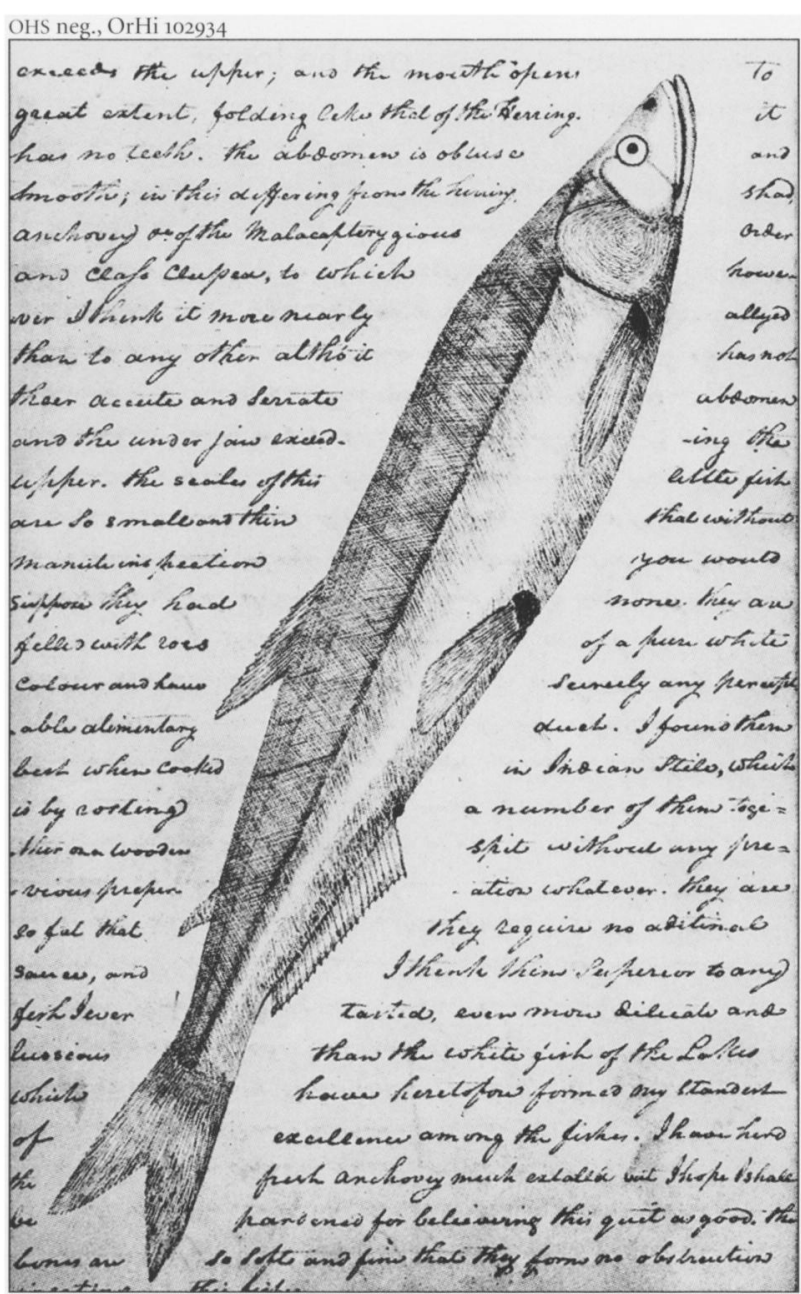

Clark also sketched a eulachon in his journal. The explorers were especially fond of the taste of this fish, which they referred to as "anchovie." Lewis wrote that they were "superior to any fish I ever tasted." family. ${ }^{25}$ These fish are small (five to eight inches; thirteen to twenty centimeters), rich in oil, and have an anadromous life cycle like Pacific salmon and trout. Historically, they entered the Columbia in dense schools from December through February and spawned in tributary streams - mainly the Cowlitz, Lewis, and Sandy rivers - within 160 kilometers of the Columbia's mouth. ${ }^{26}$ They form an important part of the food chain for predatory fish, particularly sturgeon, which would cluster in eulachon spawning areas to take advantage of the temporary spike in abundance. ${ }^{27}$ Apparently, Native Americans and members of the Lewis and Clark Expedition took advantage of this food chain as well. Indians trading with the Corps in February and March were often selling both sturgeon and eulachon, suggesting that the fish were captured at roughly the same time and place.

\section{What Fish Did Lewis and Clark Eat on the Lower Columbia?}

JouRNAL ENTRIES for the period the Corps spent on the lower river reveal the importance of fish to the group's survival and also show that expedition members spent very little time actually fishing. Hunting for elk, which provided both food and clothing, was a much more common activity. Among the 163 days of journal entries during the period when the expedition was in the area, the explorers mentioned fish as food items on 32 days, or about 20 percent of the time (see table 2). Although on many days fish 
Table 2. Frequency that fish are mentioned as food on the lower Columbia and how they were procured (November 2, 1805April 13, 1806)

\begin{tabular}{lc}
\hline Manner of procurement & $\begin{array}{l}\text { Number of days } \\
\text { noted as food item }\end{array}$ \\
\hline Trade or gift from Indians & 22 \\
Pounded/dried fish obtained from Indians & 8 \\
Expedition members fishing & 2 \\
Total & 32 \\
\hline
\end{tabular}

supplemented elk or plant foods, especially the potato-like root wapato, Sagittaria latifolia, on eight days between November 13 and December 25 Clark reported that fish was their main food item. For example:

November 13: nothing to eate but pounded fish which we Keep as a reserve and use in Situations of this kind.

November 25: ... we Dined in the Shallow Bay on Dried pounded fish ...

November 29: our diat at this time and for Severall days past is the dried pounded fish we purchased at the falls boiled in a little Salt water-.

December 2: I am verry unwell the drid fish which is my only diet does not agree with me and Several of the men Complain of a lax, and weakness - ${ }^{28}$

The dried or pounded fish was salmon, particularly chinook salmon (O. tshawytscha), which the Corps had purchased in the vicinity of The Dalles, about three hundred kilometers (about 185 miles) upriver from the mouth of the Columbia. ${ }^{29}$ While the entries suggest that expedition members would have much preferred other foods, particularly fresh red meat, dried fish was available and provided essential sustenance in November and December, when hunting was not successful. It is reasonable to suggest that expedition members would not have survived winter on the Oregon coast without fish.

Besides the use of dried fish from their private stores, twenty-two journal entries describe fish being obtained through trade or as gifts from Indians, including freshly caught "red charr" (one day), sturgeon (thirteen days), "anchovie" (six days), and "salmon trout" (two days). On several occasions, the Corps also obtained dried fish (eulachon and probably salmon) from Indians. Sturgeon and eulachon became an especially common trade item in February and March, at the onset of the eulachon run. 
Aside from basic sustenance, expedition members appreciated the flavor and richness of these two fish, especially eulachon. As Lewis wrote:

February 24: The chief and his party had brought for sail a Sea Otter skin some hats, stergeon and a [s] pecies of small fish which now begin to run, and are taken in great quantities in the Columbia R. about 40 miles above us by means of skimming or scooping nets.... they are so fat they require no additional sauce, and I think them superior to any fish I ever tasted, even more delicate and lussious than the white fish of the lakes which have heretofore formed my standart of excellence among the fishes.... the Sturgeon which they brought us was also good of it's kind.

March 11: Early this morning Sergt. Pryor arrived with a small canoe loaded with fish which he had obtained from the Cathlahmah's for a very small part of the articles he had taken with him.... we once more live in clover; Anchovies fresh Sturgeon and Wappetoe..$^{30}$

Overall, the journals suggest that fish were at times an essential and at times a supplementary source of food while the Corps sojourned on the lower river. It is curious, then, that the expedition members spent so little time fishing. ${ }^{31}$ On November 12 and ${ }_{13}$, Clark and some of his men caught about sixteen "salmon trout" that were in creeks on the north side of the estuary. On one other occasion, expedition members possibly caught their own fish. After the eulachon began to run in late February, Lewis reported that three men were sent

up the Columbia River to take sturgeon and Anchovey. or if they were unsuccessfull in fishing we directed them to purchase fish from the natives for which purpose we had furnished them with a few articles such as the natives are pleased with. ${ }^{32}$

The group returned on March 2, Lewis recorded, with a "most acceptable supply of fat Sturgeon, [and] fresh Anchovies," although he did not specify whether the men procured the fish themselves or traded for them..$^{33}$ In general, the journals are clear: time and resources were not spent trying to catch fish but instead were focused on hunting terrestrial game, particularly elk and, to a lesser extent, deer. Between December 1 and March 10, members of the expedition killed 116 elk and 14 deer. ${ }^{34}$ Entries such as these by Clark are common:

Indians in the Columbia River Basin used a variety of fish nets and traps, including the forms shown at right. On January 16, 1806, Meriwether Lewis reported: "The Clatsops Chinnooks $\checkmark v$. in fishing employ the common streight net, the scooping or diping net with a long handle, the gig, and the hook and line.... the skiming or [s]cooping net to take small fish in the spring and summer season; the gig and hook are employed indiscriminately at all seasons in taking such fish as they can procure by their means." 


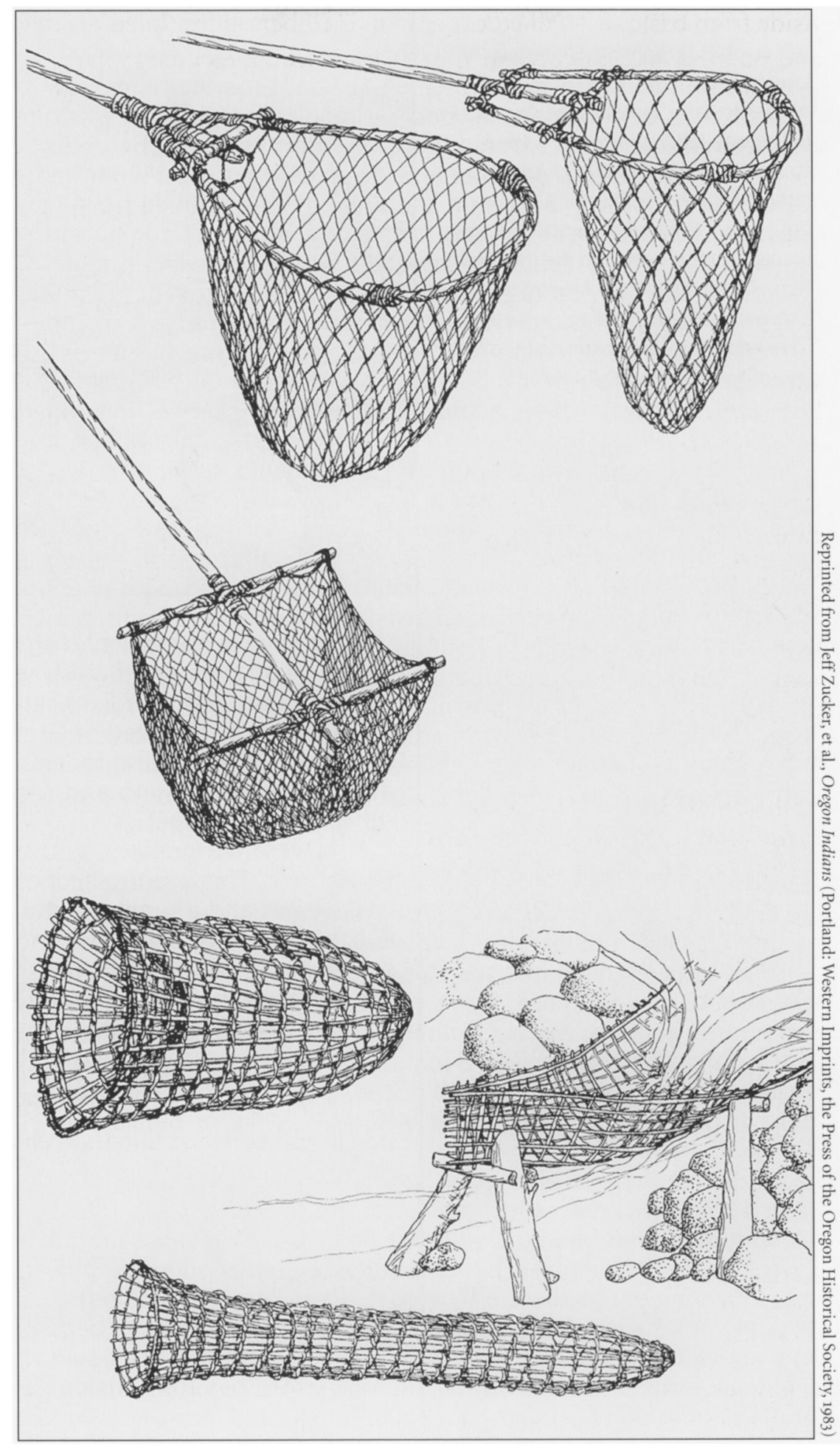

Butler, Where Have All the Native Fish Gone? 
December 9: ... Send 2 men in pursute of the Elk ...

December 27: ... Sent out R. Fields \& Collins to hunt and order Drewyer, Shannon \& Labiach to Set out early to morrow to hunt ...

December 29: ... Sent out 3 men across the river to hunt ... ${ }^{35}$

Why did the Corps focus so much attention on hunting over fishing? One reason is linked to cultural preference: many entries indicate how much the group preferred red meat to fish. A more general explanation appeals to foraging models from evolutionary ecology that rank food resources according to the returns they provide. ${ }^{36}$ The prey-choice model suggests that a predator's most efficient strategy is to focus on the highestranked resources - those that provide the greatest returns - and to shift to lower-ranked resources only when the density of high-ranked prey is reduced. Body size is a good proxy measure for rank: the larger the animal, the higher the return rate, up to a certain point. ${ }^{37}$ Thus, relative to fish, large game such as elk would be a higher-ranked prey and the first-choice food, unless their abundance was depressed. Factors such as capture method or whether prey is captured singly or as a group obviously affect return rate. ${ }^{8}$ These factors would also work in favor of elk, in that the expedition had firearms that were effective for hunting and they lacked knowledge of fish habits and distribution and effective means of capture. As well, the expedition was in the area at a time of year when salmon were least abundant, which also would have tilted the balance in favor of pursuing terrestrial game.

In short, fish were an important component of the expedition's diet, despite the group's cultural preferences and main subsistence activities. Their records of the fish they ate and observed provide valuable information about fish populations in the lower Columbia in the nineteenth century, prior to major changes associated with Euro-American activities. Fish remains excavated from archaeological sites representing villages that Lewis and Clark visited extend our knowledge about the fish present and their distribution in the region at the time.

\section{What Do Archaeological Fishbone Records Tell Us?}

Journal entries referring to Native Americans on the lower Columbia commonly describe Native practices of catching, cooking, storing, selling, and transporting fish. According to the expedition journals, fish formed the major part of Native American subsistence. ${ }^{39}$ It is not surprising, then, that the archaeological record of Native Americans includes large numbers of fish bones and teeth. Cathlapotle, one of the villages the 


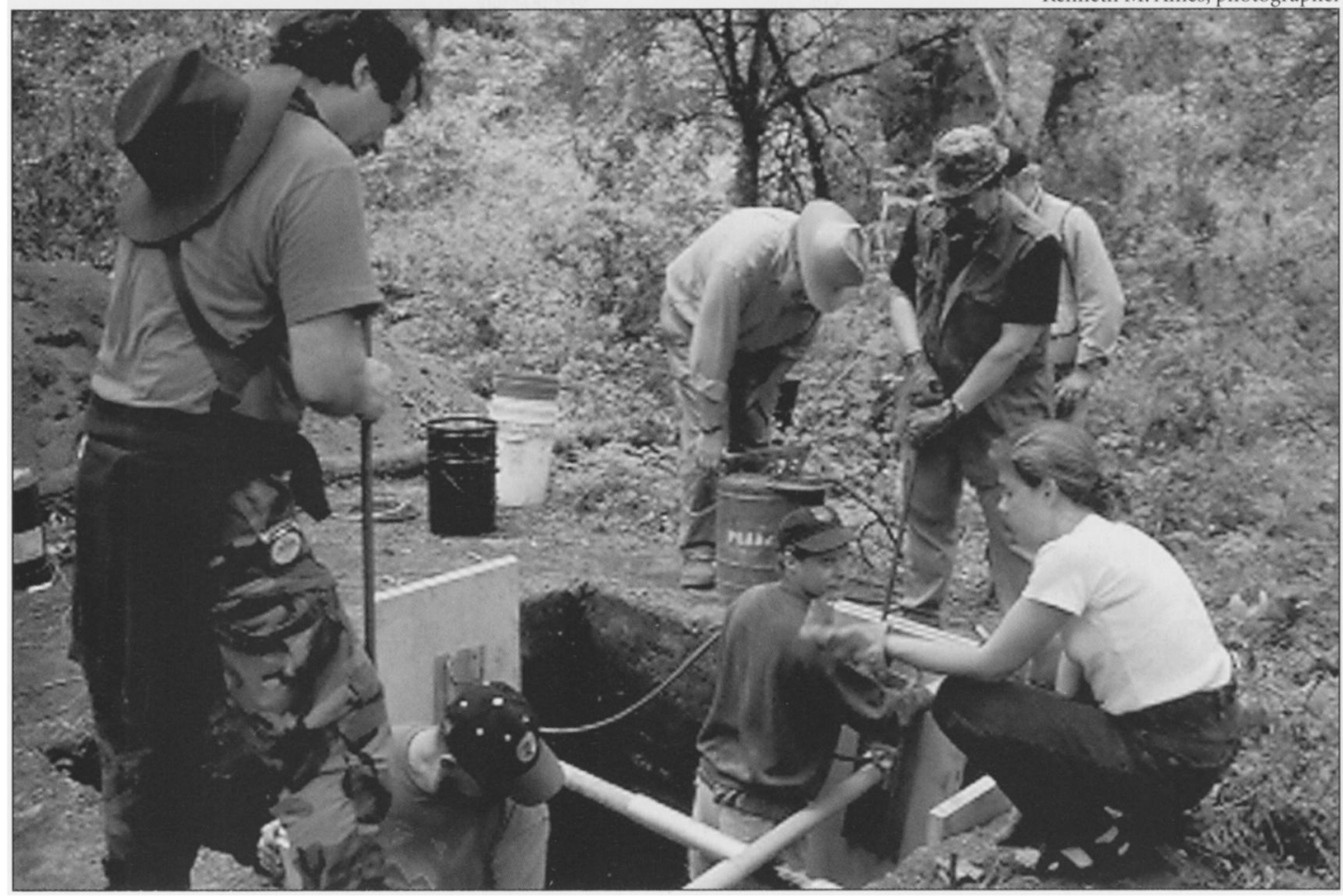

Portland State University students and staff excavating at Cathlapotle (45CL1), one of the villages the expedition visited on their journey both downstream and upstream.

expedition visited on their journey both downstream (November 5) and upstream (March 29), is particularly important in this regard. On March 29, Lewis wrote:

we arrived at the village of the Cath [X:Qualth]-lah-poh-tle wich consists of 14 large wooden houses.... they had large quantities of dryed Anchovies strung on small sticks by the gills and others which had been first dryed in this manner, were now arranged in large sheets with strings of bark and hung suspended by poles in the roofs of their houses; they had also an abundance of sturgeon and wappetoe; ... they were very hospitable and gave us anchovies and wappetoe to eat. ${ }^{40}$

Analysis of early maps, known geographic features, historic records, and, most recently, archaeological excavation strongly suggests that the Cathlapotle village described in the journals was located on what is now the Ridgefield National Wildlife Refuge in Clark County, Washington, about thirty kilometers (about eighteen miles) north of Portland, Oregon (see map 1). These records place the village just downstream of the Lewis River on the banks of Lake River, one of many backwater sloughs that were 
Table 3. Fish identified from archaeological remains at Cathlapotle (45CL1)

\begin{tabular}{|c|c|c|}
\hline Finest taxon ${ }^{*}$ & Fish family & Common name \\
\hline Salmonidae $\mathrm{e}^{\mathrm{a}, \mathrm{b}}$ & Salmonidae & salmon, trout, whitefish \\
\hline Thaleichthys pacificus ${ }^{a}$ & Osmeridae & eulachon \\
\hline Acipenser sp. ${ }^{\mathrm{a}}$ & Acipenseridae & sturgeon \\
\hline Ptychocheilus oregonensis & Cyprinidae & northern pikeminnow \\
\hline Mylocheilus caurinus & Cyprinidae & peamouth \\
\hline Acrocheilus alutaceus & Cyprinidae & chiselmouth \\
\hline Rhinichthys osculus & Cyprinidae & speckled dace \\
\hline Catostomus macrocheilus & Catostomidae & large-scale sucker \\
\hline Gasterosteus aculeatus & Gasterosteidae & threespine stickleback \\
\hline Cottus sp. & Cottidae & sculpin \\
\hline Percopsis transmontana & Percopsidae & sandroller \\
\hline
\end{tabular}

* Most specific taxonomic level identified.

${ }^{a}$ Listed in Lewis and Clark journals for the lower Columbia

${ }^{\mathrm{b}}$ Most probably represent anadromous salmon and trout in the genus Oncorhynchus

once common on the floodplain of the lower river and that provided a rich supply of fish to the Native population.

This village site (45CL1) has been the focus of large-scale excavation under the direction of Kenneth M. Ames of Portland State University and in collaboration with the U.S. Fish and Wildlife Service and the Chinook Tribe. ${ }^{41}$ Based on radiometric dating, artifact forms, and ethnohistoric accounts, scholars have established that the village site was mainly occupied between about 1450 and 1835. Excavation resulted in the recovery of over eleven thousand fish bones and teeth that I identified to species or family. ${ }^{42}$

Table 3 lists the fish documented from the Cathlapotle deposits. Three fish discussed at length in the journals - salmon or trout, eulachon, and sturgeon - are present. Eight additional fish occur in the archaeological deposits but are not noted in the journals, including four species of minnow (Cyprinidae) as well as sucker, threespine stickleback, sculpin (species unknown), and sandroller. Oral traditions and nineteenth-century Euro-American accounts indicate that lamprey (Lampetra sp.) was also important to Native Americans, yet remains from this fish have not 
been recovered from Cathlapotle or nearby archaeological sites..$^{43}$ The absence could certainly be linked to preservation, since the lamprey skeleton lacks true bone and teeth. Tooth-like structures in the oral disc are made of chitin (the same material that forms crab shell) and may be preserved in certain settings but have not been recovered to date.

The salmonid remains are mainly from large fish represent-
Figure 1. Frequency of fish remains identified from the Cathlapotle village site ( $45 \mathrm{CL} 1$ )

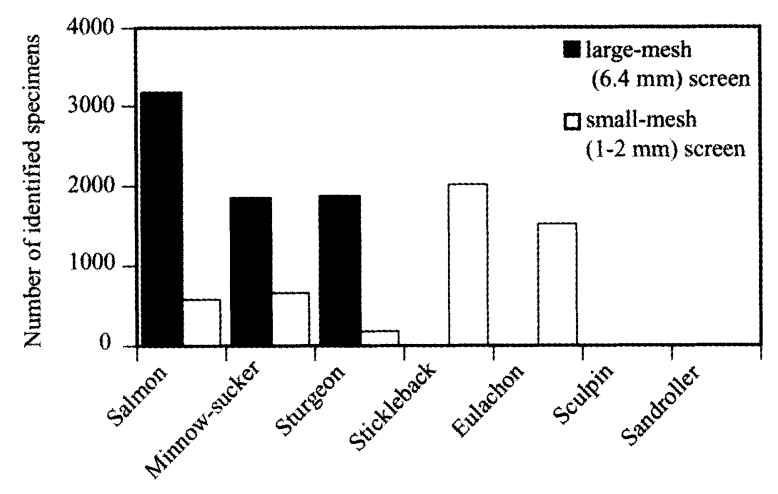
ing adults that were migrating upriver to spawn. They would have been most easily caught at falls or constrictions in the river - at the Cascades of the Columbia, for example, or Willamette Falls - or using nets and weirs on tributaries such as the Lewis River or other streams. Eulachon as well would have been caught during their upriver spawning migration, either in the main stem or in the Lewis River close to the site. The other fish were found in the Columbia's main stem and tributaries but would also frequent the warmer, slower waters of backwater sloughs and lakes on the floodplain. Moreover, the minnows and suckers, sturgeon, and stickleback would have been easiest to catch and most concentrated in the backwaters, especially in late summer when the water level would have been much reduced and fish could be speared or collected using nets in the shallows. Modern fish records from Vancouver Lake near Vancouver, Washington, indicate that the biomass of resident freshwater fish captured in a given sampled area is over ten times that in the Columbia River. ${ }^{44}$ If these records are at all comparable to conditions two hundred years ago, then they suggest that backwater habitats held a significant concentration of fish that was likely targeted by Native Americans.

Figure 1 displays a crude measure of the relative abundance of different fish in the Cathlapotle deposits by showing the frequency of specimens identified by fish family or group and by excavation recovery method. Most of the excavated sediment was sifted through large-mesh screens (6.4 $\mathrm{mm}$ ), a process that tends to recover remains from relatively large-bodied (and large-boned) fish. Salmonids dominate this large-mesh sample, with minnow-sucker and sturgeon contributing fewer specimens. Very small fish (stickleback, eulachon, sculpin, and sandroller) are extremely rare. To identify the numbers of these very small fish in the deposits, a small 


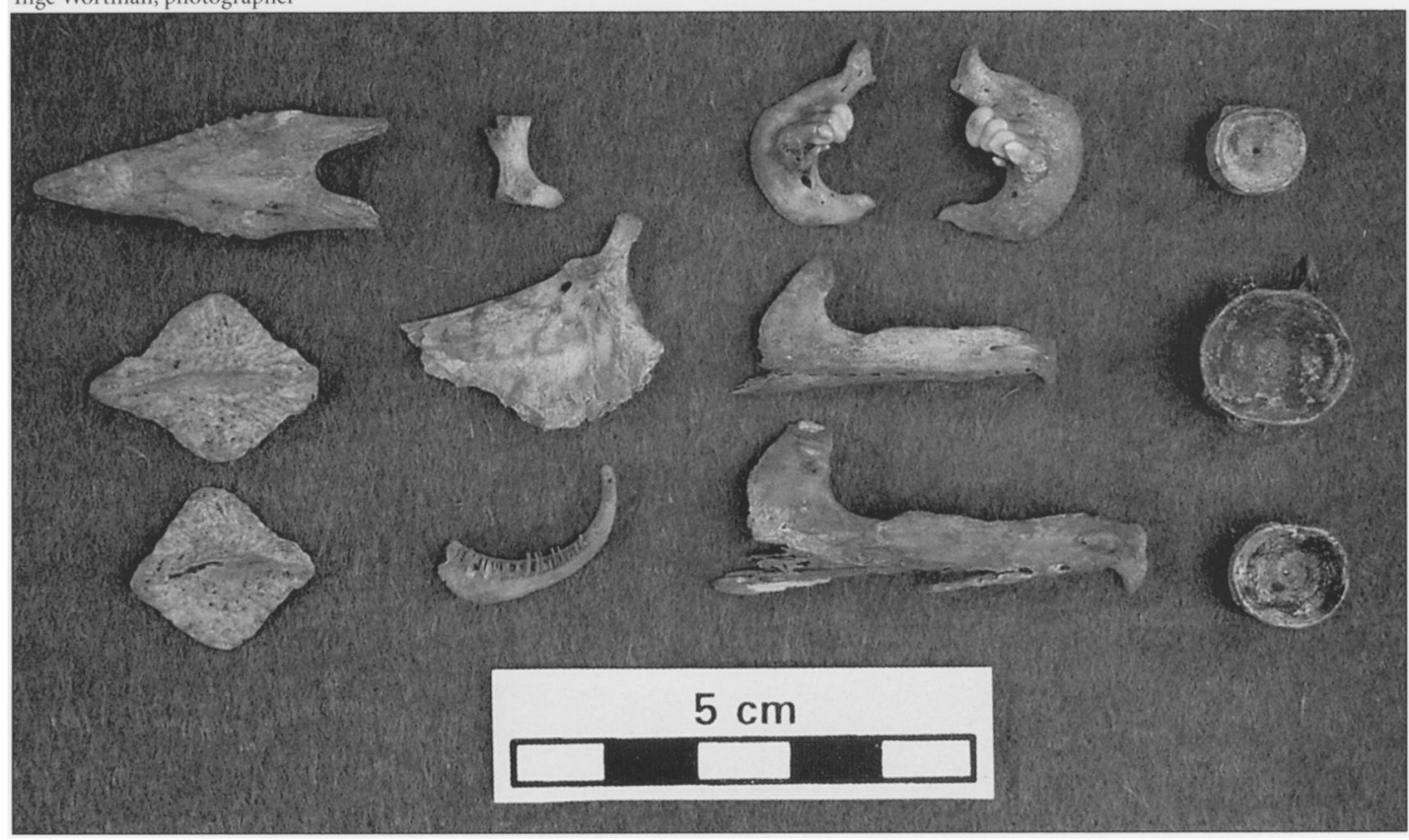

Fish remains found at Cathlapotle, in columns from left to right: Acipenser sp. (sturgeon) scutes Catostomus sp. (sucker) ceratohyal, opercle, pharyngeal; Mylocheilus caurinus (peamouth minnow) pair of pharyngeals, Ptychocheilus oregonensis (northern pike minnow) dentaries; Oncorhynchus (salmon) vertebrae.

volume of sediment (less than a hundredth of the volume for the site as a whole) was sifted through small-mesh screens ( 1 or $2 \mathrm{~mm}$ ) to recover very small fish bones. Stickleback and eulachon remains are common in the small-mesh samples. If more sediment had been screened with fine mesh, the frequency of small fish remains would likely exceed that of the large-bodied fish.

Cathlapotle is one of many archaeological sites in the PortlandVancouver metropolitan area where fish remains have been studied. ${ }^{45}$ While the composition of fish remains at these sites varies - in some sites, minnows and suckers have higher representation than salmon, for example - overall, the same fish species are represented. Besides their significance for understanding aboriginal fisheries, these kinds of fish records joined with eyewitness historic accounts, such as those from the Lewis and Clark journals, provide valuable baseline information on the distribution and abundance of native fish prior to the major habitat alteration and introduction of exotic fish that occurred with Euro-American settlement. 


\section{Lower Columbia Fishes ta. 2000}

The fish species on which Lewis and Clark most relied — salmon and trout

- have experienced major declines since the early 1800 . The dramatic decline in salmon and trout is a familiar story: of the estimated 10 to 16 million fish that migrated up the Columbia yearly before Euro-American settlement, only about 2.5 million make the journey today. The majority of these are hatchery reared. ${ }^{46}$ Since 1991, most Columbia River Basin stocks of salmon and steelhead have been listed as endangered under the Federal Endangered Species Act and are on the brink of extinction. ${ }^{47}$

Sturgeon and eulachon are faring somewhat better. Sturgeon are extremely vulnerable to overexploitation; they are slow growing, mature at a relatively old age (greater than ten years), and can live more than a hundred years. ${ }^{48}$ Sturgeon (mainly white sturgeon) became the focus of a major commercial fishery on the lower Columbia in 1889 , which peaked in 1892 when 2.5 million kilograms of fish were captured. In 1899, however, only 45,500 kilograms of fish were taken. ${ }^{49}$ The collapse in the fishery was due to overfishing. Some restrictions were placed on the fishery in the early twentieth century, but sturgeon populations on the lower Columbia did not rebound to sufficient levels to allow much fishing until the 1950 . Since then, commercial and recreational sturgeon fisheries have been monitored for legal size, size of catch, and season to ensure long-term survival of the fish. In 1995, biologists estimated there were more than 1 million white sturgeon on the lower Columbia (below Bonneville Dam). While populations declined somewhat between 1995 and 2003, additional regulations in the fishery have been added, and managers are hopeful that the populations will remain stable..$^{\circ}$ On the other hand, white sturgeon populations are not doing well on stretches of the Columbia blocked by dams upriver of Bonneville. Some populations are so reduced that they can support little fishing pressure. ${ }^{51}$ One white sturgeon population on the Kootenai River of the upper Columbia system in Montana and Idaho was listed as endangered in 1994.

Concerns also have been raised about the green sturgeon, which is much rarer and less studied than white sturgeon. It is confined to the lower stretches of large rivers from Mexico to Alaska and spends a larger part of its life cycle at sea than the white sturgeon does. In 2001, several conservation groups petitioned the National Oceanic and Atmospheric Administration's fisheries division (NOAA Fisheries) to list the species as endangered or threatened because of several concerns: the limited number of known spawning locations (three - on the Sacramento, Klamath, and 
Rogue rivers), the small size of spawning populations, and the limited knowledge of the ecology and population structure of the species. ${ }^{52}$ In January 2003, NOAA rejected the petition but agreed to consider green sturgeon a candidate species, a status that encourages but does not legally require agencies to work toward species conservation. In March 2004, a U.S. district court set aside this finding, however, and required that the agency reconsider whether the species is endangered or threatened in parts of its range. ${ }^{53}$ Overall, the long-term survival of green sturgeon is uncertain.

There is some question about the current status of eulachon. In general, the abundance of the fish as estimated from commercial catch fluctuates greatly. Catch statistics go back to 1938, and years with very low catches are followed by years with extremely large catches. Much of the variation is thought to be due to changes in ocean productivity, since the fish spend most of their lives at sea. Until 1994, the Columbia River had the world's largest run of eulachon and supported large commercial and recreational fisheries, which were little regulated. ${ }^{54}$ The situation changed in 1994, when the abundance of eulachon was extremely low and fisheries managers imposed the first major restrictions on the Columbia River fishery. In 1999, a petition was submitted to have the fish listed as threatened or endangered under the Endangered Species Act.5 NOAA Fisheries rejected the petition, citing the ability of the species to rebound from low abundance given its high fecundity and short life span and arguing that the fish was likely more abundant than commercial records suggested..$^{56}$ The agency acknowledged the severity of the decline of the 1990s and advised state and tribal fishery biologists to obtain additional information on the life history and abundance of the species to allow for effective management and to guide future policy decisions. Between 2000 and 2003, the Columbia River eulachon population apparently increased in size, as documented by larval fish abundance (indicating successful spawning of returning adults) and increases in the commercial and sport fishery, which are close to levels from the early 1990s. ${ }^{57}$ Experts hope that these high returns of recent years will continue.

Besides the declines in the major Columbia River fisheries - salmon and trout, sturgeon, and eulachon - the composition of backwater lake and slough fish populations has changed drastically in the past two hundred years. The archaeological fish record suggests that several species of minnows and suckers dominated these areas before Euro-American arrival (see figure 1). Today, a variety of exotic fish species (e.g., bluegill, crappie, bass, carp) prevail, introduced mainly from eastern North America. The backwater aquatic system has also been greatly altered in the past 150 years. 
Table 4. Summary information from 1980 os fisheries studies in metropolitan Portland, Oregon-Vancouver, Washington

\begin{tabular}{|c|c|c|c|c|c|c|}
\hline \multirow[b]{2}{*}{ Project } & \multirow{2}{*}{$\begin{array}{c}\text { Duration of } \\
\text { sampling (years) }\end{array}$} & \multirow{2}{*}{$\begin{array}{l}\text { Total fish } \\
\text { captured }\end{array}$} & \multicolumn{2}{|c|}{ Native species } & \multicolumn{2}{|c|}{ Exotic species } \\
\hline & & & \# & $\%$ & $\#$ & $\%$ \\
\hline $\begin{array}{l}\text { Lake River- } \\
\text { Vancouver Lake }\end{array}$ & 2.5 & 5516 & 7 & 37 & 12 & 63 \\
\hline $\begin{array}{l}\text { Columbia Slough- } \\
\text { Bybee Lake }\end{array}$ & .5 & 685 & 6 & 38 & 10 & 63 \\
\hline
\end{tabular}

Source: Paul A. Fishman, "Smith and Bybee Lakes Environmental Studies, Technical Appendix G: Fish" (Portland, Ore.: Port of Portland, City of Portland, Bureau of Environmental Services, 1986); John A. Knutzen and Rick D. Cardwell, "Revised Draft Final Report for the Fisheries Monitoring Program, Vancouver Lake Restoration Project" (Portland, Ore.: Envirosphere Company for Cooper Consultants, Inc., 1984)

Extensive wetlands have been drained to provide land for agriculture and industrial development. In addition to local land-filling and dike construction, main-stem dams on the Columbia greatly reduce seasonal flooding and, by breaking up the river into a series of reservoirs, create conditions that are extremely attractive to exotic fish..$^{88}$

Results from two fisheries projects carried out between 1982 and 1986 in the metropolitan areas of Portland, Oregon, and Vancouver, Washington, indicate the kinds and abundance of fish now inhabiting the backwater areas of the lower Columbia. One study focused on the Lake RiverVancouver Lake region..$^{59}$ Each month for two and a half years, fish were collected using nets and traps of varying mesh size at twelve stations. A second study focused on what are now industrialized areas and wetlands of north Portland along Columbia Slough and Bybee Lake. ${ }^{60}$ Fish were collected at monthly or bi-monthly intervals between May and October, mainly using electrofishing at twenty-nine stations. In both cases, fish were identified by species, counted, and weighed. Sampling focused on backwater areas, and thus the results highlight the composition of fish that thrive in backwater lakes and channels rather than the colder, fasterflowing Columbia. Given that fish populations are dynamic and are likely to vary over longer time frames than the sampling interval (six months to two and a half years), the catch data offer only rough estimates. Other studies show the prominence of exotic fish elsewhere on the Columbia, and thus it is reasonable to suggest that trends seen in the two Portland metro projects are widespread. ${ }^{6}$

Non-native fish dominated the collections from these two studies in all ways of calculating abundance (see tables 4 and 5). Non-native fish constituted over half of the species present in each area (63 percent), and 
Table 5. Species and frequency of fish captured in 1980s fisheries studies

\begin{tabular}{|c|c|c|}
\hline Species & $\begin{array}{l}\text { Columbia Slough- } \\
\text { Bybee Lake }\end{array}$ & $\begin{array}{l}\text { Lake River- } \\
\text { Vancouver Lake }\end{array}$ \\
\hline \multicolumn{3}{|l|}{ Exotic-Introduced } \\
\hline Alosa sapidissima (American shad) & 0 & 11 \\
\hline Cyprinus carpio (carp) & 178 & 641 \\
\hline Carassius auratus (goldfish) & 28 & 37 \\
\hline Ictalurus nebulosus (brown bullhead) & 3 & 62 \\
\hline Ictalurus punctatus (channel catfish) & o & 6 \\
\hline Micropterus salmoides (large-mouth bass) & 35 & 14 \\
\hline Pomoxis nigromaculatus (black crappie) & 18 & 1982 \\
\hline Pomoxis annularis (white crappie) & 70 & 1961 \\
\hline Lepomis macrochirus (bluegill) & 121 & 89 \\
\hline Lepomis gibbosus (pumpkindseed) & 10 & 2 \\
\hline Lepomis gulosis (warmouth) & 2 & 1 \\
\hline Perca flavescens (yellow perch) & 57 & 49 \\
\hline Total & 522 & 4855 \\
\hline \multicolumn{3}{|l|}{ Native } \\
\hline Acipenser transmontanus (white sturgeon) & o & 46 \\
\hline Salmonidae (salmon and trout) & 76 & 21 \\
\hline Ptychocheilus oregonensis (northern pikeminnow) & 21 & 30 \\
\hline Mylocheilus caurinus (peamouth) & 15 & 272 \\
\hline Catostomus macrocheilus (large-scale sucker) & 44 & 259 \\
\hline Cottidae (sculpin family) & 5 & 3 \\
\hline Platichthys stellatus (starry flounder) & $\underline{2}$ & 30 \\
\hline Total & 163 & 661 \\
\hline
\end{tabular}

Source: Paul A. Fishman, "Smith and Bybee Lakes Environmental Studies, Technical Appendix G: Fish" (Portland, Ore.: Port of Portland, City of Portland, Bureau of Environmental Services, 1986); John A. Knutzen and Rick D. Cardwell, "Revised Draft Final Report for the Fisheries Monitoring Program, Vancouver Lake Restoration Project” (Portland, Ore.: Envirosphere Company for Cooper Consultants, Inc., 1984)

the majority of fish in the system were non-native. Black crappie and white crappie dominated the Lake River-Vancouver Lake catch, and carp was the third most abundant fish (see figure 2a). All three species are introduced. Native fish made up less than 12 percent of the catch. In the Columbia Slough-Bybee Lake study, the exotic carp dominated, making 
up 26 percent of the catch by count and between 42 and 97 percent by weight, with variation across monthly samples (see figure $2 \mathrm{~b}$ ). Overall, only 24 percent of the fish captured were native fish.

Exotic fish were first introduced into the Columbia system in the 1870 . Between 1880 and 1930 , at least fifteen species were introduced to the river and wetlands. Mainly transplanted from eastern North America, most of the exotics have been extremely successful in the relatively warm, slow, backwater habitats of the lower river and in the reservoirs created by dams farther upstream. ${ }^{62}$ Private citizens as well as federal and state fishery programs introduced the non-native fish. While some introductions were accidental, either as aquarium releases or from the disposal of bait buckets, most of the introductions were deliberate, intended to provide food for human con-
Figure 2a. Frequency of fish captured at Lake River-Vancouver Lake

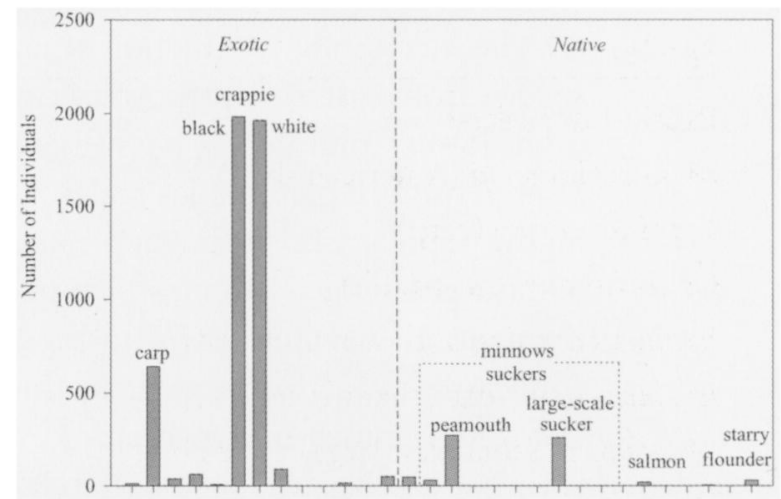

Only selected species are labeled. Source: Knutzen and Cardwell, "Revised Draft Final Report for the Fisheries Monitoring Program, Vancouver Lake Restoration Project."

Figure 2b. Frequency of fish captured at Columbia SloughBybee Lake

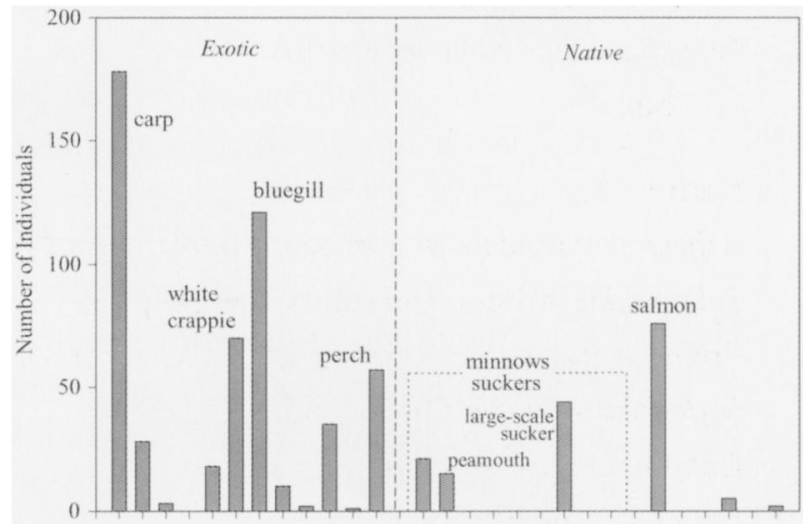

Only selected species are labeled. Source: Fishman, "Smith and Bybee Lakes Environmental Studies."

sumption or forage for other fish, biological control of unwanted animal or plant pests, or sport-fishing opportunities..$^{63}$ Non-native fish were and continue to be the target of major sport fisheries and offer a large source of revenue for local communities in Oregon and Washington, as well as for fishery agencies from licensing fees. ${ }^{64}$ Early in the introduction process, biologists saw mainly the positive effects of the transplants, whereas today researchers are much more aware of the ways exotic fish harm native fish and habitats. ${ }^{65}$ Non-native fish are known to prey on native fish, to compete with natives for food or space, and sometimes to cause major habitat changes that lead to declines in native wildlife, and in some cases, species 
extinctions. ${ }^{66}$ Given these concerns, state and federal fishery agencies in the Pacific Northwest have established policies for regulating introductions.

The successful introduction of non-native fish - such as the suite of species from eastern North America that now dominate aquatic habitats in the lower Columbia - has the general effect of homogenizing wildlife at larger and larger spatial scales. ${ }^{67}$ Cosmopolitan species, such as the highly popular game fish crappie and bass, are analogous to McDonald's hamburgers, which can now be purchased throughout the world. Just as regional cultural cuisines are losing their distinctive flavors, regional fish communities are losing their distinctiveness. The lower Columbia has changed so much in two hundred years that if Lewis and Clark threw their net in a backwater slough today, they would recognize eight out of ten fish they caught because they would have seen them in the streams and rivers where the explorers had grown up.

S WE CONSIDER THE ANNIVERSARY of Lewis and Clark's journey,
which contributed to the settlement of the American West
by Euro-Americans, close examination of the extent of change
in Columbia River fish populations offers opportunities to consider the ways in which people of the region draw much of their history and cultural pride from these impressive creatures. Native peoples have an ancient connection to our region's fish. Fish were and continue to be a source of food as well as a component of Indian peoples' belief systems about the origin of the world and their place in it. ${ }^{68} \mathrm{~A}$ recent ethnohistorical study has suggested that the state name for Oregon might have its root in the Indian word for eulachon, of which Captain Lewis especially was so fond. ${ }^{69}$ Euro-American settlement in the nineteenth century was fueled in part by the bounty of Columbia River fisheries. William L. Lang has recently argued that the history of fishing regulations and continuing public support for efforts to keep salmon plentiful in our rivers illustrates just how much Indians and non-Indians alike revere these fish..$^{\circ}$ Most of us are aware that salmon populations are in severe decline and much reduced from Lewis and Clark's time. There is much less awareness that most native fish are in decline or are being replaced by alien species.

Lewis and Clark's accounts and archaeological fishbone records provide benchmarks for local fauna prior to the species introductions and habitat modifications that followed the expedition. By comparing fish records from around two hundred years ago to those of today, the magnitude of the faunal changes in specific locales becomes clear. Remarkably, in the space of just two hundred years, Northwest fish populations have undergone 
drastic declines, and many populations are on the verge of extinction. By establishing the ancient history of the native fish of the lower Columbia through history and archaeology, the case can be made that these creatures deserve a place here long into the future.

\section{Notes}

A number of people provided assistance with this project and manuscript and have my deepest gratitude: Ken Ames, Bill Lang, Paul Fishman, Lenora Oftedahl, Joy Margheim, Kevleen Melcher, Hiram Li, Dave Ellis, Andrew Fountain, Jim O'Connor, Alex Bourdeau, Anan Raymond, Stephanie Butler, Michael Martin, Mike Mayhew, Greg Baker, and Fred Anderson. The U.S. Fish and Wildlife Service provided financial support for analysis of fish remains. I also thank the Chinook Tribe and Tribal Council, U.S. Fish and Wildlife Service, Portland State University, and the people of Ridgefield, Washington, for their continuing support for the Cathlapotle project since 1990.

1. Luther S. Cressman et al., Cultural Sequences at the Dalles, Oregon: A Contribution to Pacific Northwest Prehistory, Transactions of the American Philosophical Society, vol. 50-10 (Philadelphia: American Philosophical Society, 1960); Virginia L. Butler and Jim E. O'Connor, "9ooo Years of Salmon Fishing on the Columbia River, North America." Quaternary Research 62 (2004): 1-8.

2. Northwest Power and Conservation Council, "Compilation of Information on Salmon and Steelhead Losses in the Columbia River Basin (Appendix D)," in "Estimates of HydropowerRelated Losses, Technical Appendix F" (Portland, Ore.: Columbia River Fish and Wildlife Program, 2000), 7 .

3. Elliott Coues, ed., The History of the Lewis and Clark Expedition by Meriwether Lewis and William Clark, vol. 3 (New York: Dover, 1893); Raymond D. Burroughs, Natural History of the Lewis and Clark Expedition (East Lansing: Michigan State University Press, 1961); Paul R. Cutright, Lewis and Clark: Pioneering Naturalists (1969; reprint, Lincoln: University of Nebraska Press, 1989); Gary E. Moulton, ed., The Definitive Journals of Lewis and Clark, vol. 6 (Lincoln: University of Nebraska Press, 1990).

4. Moulton, ed., Journals, 6:40.

5. Cutright, Lewis and Clark, 270; Burroughs, Natural History, 261; Moulton, ed., Journals, 6:414.

6. Leonard A. Fulton, Spawning Areas and Abundance of Steelhead Trout and Coho, Sockeye, and Chum Salmon in the Columbia River Basin - Past and Present (Washington, D.C.: U.S. Fish and Wildlife Service, 1970), 23-9.

7. Ibid., 12-23, 29-32.

8. Moulton, ed., Journals, 6:411.

9. Fulton, Spawning Areas, 12.

10. Moulton, ed., Journals, 6:27, 42-4. Taxonomic revision now places steelhead trout in genus Oncorhynchus. O. mykiss replaces the former species name, Salmo gairdneri.

11. Ibid., 413.

12. Ibid.

13. Fulton, Spawning Areas, 3-12.

14. Burroughs, Natural History, 261; Cutright, Lewis and Clark, 270.

15. Moulton, ed., Journals, 6:423, 7:102.

16. Ibid., 6:421-2.

17. Ibid., 63; Coues, ed., History, 891; J.L. Hart, Pacific Fishes of Canada (Ottawa: Fisheries Research Board of Canada, 1973), 595-639.

18. Moulton, ed., Journals, 6:175.

19. Ibid., 6:178; Coues, ed., History, 891.

20. William N. Eschmeyer and Earl S. Herald, A Field Guide to Pacific Coast Fishes of North America (Boston: Houghton Mifflin, 1983), 47-53; Hart, Pacific Fishes, 54-62

21. Moulton, ed., Journals, 6:70.

22. Coues, ed., History, 716.

23. Hart, Pacific Fishes, 82.

24. Moulton, ed., Journals, 6:70.

25. Lewis and Clark used the term "anchovie" or "anchovey" for this fish, which is actually the common name for the family, Engraulidae.

26. Joseph A. Craig and Robert L. Hacker, "The History and Development of the Fisheries of the Columbia River," Bulletin U.S. Bureau of Fisheries 49 (1940): 208-9.

27. Hart, Pacific Fishes, 150.

28. Moulton, ed., Journals, 6:45, 87, 93, 105.

29. The Corps purchased four "sacks" from "Friendly Village" near present-day Lyle, Washington, on October 29, 1805. Moulton, ed., Journals, 5:349.

30. Moulton, ed., Journals, 6:342, 344, 401-2. 31. See also Stephen E. Ambrose, Undaunted Courage: Meriwether Lewis, Thomas Jefferson, and the Opening of the American West (New York: Simon \& Schuster, 1996), 322. Ambrose noted that the lack of fishing on the lower Columbia was particularly striking, given the extent that expedition 
members had fished on the Missouri Piver.

32. Moulton, ed., Journals, 6:351.

33. Ibid., 6:368

34. Andrea Laliberte and William J. Ripple, "Wildlife Encounters by Lewis and Clark: A Spatial Analysis of Interactions between Native Americans and Wildlife," Bioscience 53 (2003): 998.

35. Moulton, ed., Journals, 6:117, 138, 141.

36. Eric L. Charnov, "Optimal Foraging: T'he Marginal Value Theorem," Theoretical Population Biology 9 (1976): 474-98; Jack M. Broughton, Resource Depression and Intensification during the Late Holocene, San Francisco Bay: Evidence from the Emeryville Shellmound Vertebrate Fauna Anthropological Records, vol. 32 (Berkeley: University of California Press, 1999); Virginia L. Butler, "Resource Depression on the Northwest Coast of North America," Antiquity 74 (2000): 649-61.

37. As Broughton notes, larger prey have overall higher energetic values related to nutrition - energy, protein, fat, and raw materials such as hides, sinew, and bone for tools. Broughton, Resource Depression, 14.

38. David B. Madsen and David N. Schmitt, "Mass Collecting and the Diet Breadth Model: A Great Basin Example," Journal of Archaeological Science 25 (1998): $445-55$

39. Moulton, ed., Journuls, 6:190.

40. Ibid., 7:27-8.

41. Kenneth M. Ames et al., Archaeological Investigations at 45CL1 Cathlapotle (1991-1996), Cultural Resource Series no. 106 (Fortland, Ore.: U.S. Department of Interior, Fish and Wildlife Service, Region 1, 1999).

42. Virginia L. Butler, "Fish Remains from Cathlapotle: Preliminary Report" (unpublished paper in possession of author).

43. David A. Close et al.."The Ecological and Cultural Importance of a Species at Risk of Extinction, Pacific Lamprev," Fisheries 27 (2002): 19-25.

44. John A. Knutzen and Rick D. Cardwell, "Revised Draft Final Report for the Fisheries Monitoring Program, Vancouver Lake Restoration Project" (Portland, Ore.: Envirosphere Company for Cooper Consultants, 1984).

45. Richard M. Pettigrew, A Prehistoric Cultural Sequence in the Portland Basin of the Lower Columbia Valley, Anthropological Papers, vol. 22 (Eugene: University of Oregon, 1981); David V. Ellis, "Data Recovery Excavations at the Columbia Slough Site (35MU105), Multnomah County, Oregon" (Portland, Ore.: Archaeological Investigations Northwest, 1996); Ellis, "Cultural Resource Survey and Archaeological Test Excavations for the Proposed Pacific Gateway Storm Sewer Extension Project, Portland, Oregon" (Portland, Ore.: Archaeological Investigations Northwest, 1998); Ellis, "Cultural Resource Survey for the Proposed
Wapato Corrections Facility and Data Recovery Excavations at 35MU117, Portland, Oregon" (Portland, Ore.: Archaeological Investigations Northwest, 2000); Becky Saleeby, "Prehistoric Settlement Patterns in the Portland Basin of the Lower Columbia: Ethnohistoric, Archaeological and Biogeographic Perspectives" (Ph.D. diss. University of Oregon, 1983); Butler, "Resource Depression," 652 .

46. Northwest Power and Conservation Council, "Compilation of Information," 4-6.

47. Joint Columbia River Management Staff, "Joint Staff Report Concerning Commercial Seasons for Sturgeon and Smelt in 2004" (Washington Department of Fish and Wildlife, Oregon Department of Fish and Wildlife, 2003), 26, available online at www.dfw.state.or.us/ODFWhtml/InfoCntrFish/InterFish/o4wjsr.pdf (July 13, 2004); Jim Lichatowich, Salmon without Rivers: A History of the Pacific Salmon Crisis (Washington, D.C.: Island Press, 1999), xiii-xiv.

48. Richard S. Wydoski and Richard R. Whitney, Inland Fishes of Washington, 2nd ed. (Seattle: American Fisheries Society and University of Washington Press, 2003), 43.

49. Craig and Hacker, "History and Development of the Fisheries," 204-8; Bruce E. Rieman and Raymond C. Beamesderfer, "White Sturgeon in the Lower Columbia River: Is the Stock OverExploited?" North American Journal of Fisheries Management 10 (1990): 388.

50. Joint Columbia River Management Staff, "Joint Staff Report," 4.

51. Wydoski and Whitney, Inland Fishes, 44.

52. Environmental Protection Information Center, Center for Biological Diversity, and Waterkeepers Northern California, "Petition to List the North American Green Sturgeon (Acipenser medirostris) as an Endangered or Threatened Species under the Endangered Species Act," June 2001, available online at www.nmfs.noaa.gov/prot_res/ readingrm/Candidate_Plus/green_sturgeon/petition.pdf (accessed July 13, 2004).

53. NOAA, "Endangered and Threatened Wildlife and Plants: 12-Month Finding on a Petition to List North American Green Sturgeon as a Threatened or Endangered Species," Federal Register 68:19 (January 29, 2003): 4433, 50 CFR parts 223 and 224, available online at www.nmfs. noaa.gov/prot_res/readingrm/Candidate_Plus/ green_sturgeon/12-month_finding.pdf (accessed July 13, 2004); NOAA, "Endangered and Threatened Wildlife and Plants: Updated Status Review of the North American Green Sturgeon, Federal Register 69:117 (June 18, 2004): 34135-6, available online at www.epa.gov/fedrgstr/EPA-SPECIES/2004/June/ Day-18/e13802.htm (accessed July 13, 2004).

54. Division of Fisheries and Oceans, Canada 
"Eulachon," Science Stock Status Report B6-06 (1999), 2, available online at www.pac.dfo-mpo. gc.ca/sci/psarc/SSRs/Pelagic/b6-06.pdf (accessed July 13, 2004).

55. Sam Wright, "Request for Reconsideration of the National Marine Fisheries Service Decision as Described in the Federal Register 64 (228), November 29, 1999/Proposed Rules, pp. 66601-666-3: Endangered and Threatened Wildlife and Plants; 90-Day Finding for a Petition to List Columbia River Eulachon (Thaleichthys pacificus) as Endangered and Threatened," submitted to Garth Griffen, Protected Resources Division, National Marine Fisheries, Portland, Ore., 2000.

56. Andrew A. Rosenberg, "Endangered and Threatened Wildlife and Plants. 90-Day Finding for a Petition to List Columbia River Eulachon (Thaleichthys pacificus) as Endangered or Threatened," Federal Register 64:228 (1999): 66601-3.

57. Joint Columbia River Management Staff, "Joint Staff Report," 17-18.

58. Hiram W. Li et al., "Factors Influencing Changes in Fish Assemblages of Pacific Northwest Streams," in Community and Evolutionary Ecology of North American Stream Fishes, ed. William J. Matthews and David C. Heins (Norman: University of Oklahoma Press, 1987), 193-202.

59. Knutzen and Cardwell, "Revised Draft Final Report."

6o. Paul A. Fishman, "Smith and Bybee Lakes Environmental Studies, Technical Appendix G: Fish" (Portland, Ore.: Port of Portland, City of Portland, Bureau of Environmental Services, 1986).

61. Additional systematic sampling is needed to confirm that the trends shown in the two projects are widespread. Li et al., "Factors Influencing Changes"; Craig Barfoot et al., "Resident Fish Assemblages in Shallow Shorelines of a Columbia River Impoundment," Northwest Science 76 (2002): 103-17.

62. Hugh M. Smith, A Review of the History and Results of the Attempts to Acclimatize Fish and Other Water Animals in the Pacific States, Bulletin U.S. Fish Commission (Washington, D.C.: GPO, 1896); Ben Hur Lampman, The Coming of the Pond Fishes (Portland, Ore.: Binfords \& Mort, 1946); Kin Daily, "Recreational Fishery Management Issues in Oregon," in Management Implications of CoOccurring Native and Introduced Fishes: Proceedings from the Workshop, October 27-28, 1998, ed. Oregon Department of Fish and Wildlife and National Marine Fisheries (Portland, Ore.: National Marine Fisheries Service, 1999), 55-60. Introduced species are native to eastern North American waters, except carp, which is originally from Eurasia.

63. Wydoski and Whitney, Inland Fishes, 17-19.

64. Daily, "Recreational Fishery Management Issues," 55 ; Bill Zook, "Recreational and Economic Importance of Introduced Fishes in Washington," in Oregon Department of Fish and Wildlife and National Marine Fisheries, eds., Management Implications, 60

65. See, for example, Mark C. Scott and Gene S. Helfman, "Native Invasions, Homogenization, and the Mismeasure of Integrity of Fish Assemblages," Fisheries 26:11 (2001): $6 \rightarrow$ Peter B. Moyle and Theo Light, "Biological Invasions of Fresh Water: Empirical Rules and Assembly Theory," Biological Conservation 78 (1996): 149-61.

66. Robert R. Miller et al., "Extinctions of North American Fishes during the Last Century," Fisheries 14:6 (1989): 22-38; Dennis R. Lassuy, "Introduced Species as a Factor in Extinction and Endangerment of Native Species," American Fisheries Society Symposium 15 (1995): 391-6.

67. $\rightarrow$ Frank J. Rahel, "Homogenization of Fish Faunas across the United States," Science 288 (2000): 854-6; Scott and Helfman, "Native Invasions," 6-15.

68. Close et al., "Ecological and Cultural Importance," 22; Eugene S. Hunn, Nch'i-Wána, "The Big River": Mid-Columbia Indians and Their Land (Seattle: University of Washington Press, 1990), 148-66.

69. Scott Byram and David G. Lewis, "Ourigan: Wealth of the Northwest Coast," Oregon Historical Quarterly 102:2 (2001): 126-57. Byram and Lewis propose that Oregon is derived from an alternate pronunciation of eulachon, ooligan. See a general review of the topic in Lewis A. McArthur and Lewis L. McArthur, Oregon Geographic Names, $7^{\text {th }}$ ed. (Portland: Oregon Historical Society Press, 2003), 725-8; see also Ives Goddard and Thomas Love, "Oregon, the Beautiful," Oregon Historical Quarterly 105:2 (Summer 2004): 238-59.

70. William L. Lang, "Beavers, Firs, Salmon, and Falling Water: Pacific Northwest Regionalism and the Environment" Oregon Historical Quarterly 104:2 (Summer 2003): 163-4. 